\author{
ANNA CIERPKA \\ University of Warsaw
}

\title{
NARRATIVE IDENTITY OF ADOLESCENTS AND FAMILY FUNCTIONING
}

\begin{abstract}
The paper presents research conducted within the narrative psychology paradigm. Its main purpose was to explore the relationships between features of adolescents' identity narratives and their assessments of family functioning and themselves as family members. The choice of subject was motivated by current reports on identity formation difficulties in adolescence. Adolescents' narratives were subjected to quantitative and qualitative analysis. Associations between specific aspects of self-narratives and participants' perceptions of how their families functioned and how they functioned in the family system were evaluated. The results confirm the hypothesized relationships between the features of adolescents' narratives and evaluations of their families and self-assessments of their own functioning in those families. Multi-thematic, content-rich and positively evaluated self-narratives are associated with positive assessments of selected aspects of family functioning and adolescents' own functioning within the family. The following aspects of family assessment are significant: affective expression, level of emotional involvement in the family, level of control, family role performance and communication. Important factors in the self-assessment were: sense of competence in family role performance, assessment of one's communication, behavior control and affective expression.
\end{abstract}

Key words: adolescence, identity issues, family relationships, development, narratives

\section{Introduction}

There is a lot of talk nowadays about the dangers to the development of young people, including problems with identity formation (Arnett, 2000; Kroger, Martinussen, \& Marcia 2010; McLean, Breen, \& Fournier, 2010; Prinstein \& Dodge,

Address for correspondence: Anna Cierpka, Faculty of Psychology, University of Warsaw, Stawki 5/7, 00-183 Warsaw, Poland. E-mail: anac@psych.uw.edu.pl 
2008). With the ever-changing world and the abundance of behavioral models combining to make the right choice difficult, there is a lot of pressure on the development of adolescent identity. For that reason the family as the primary social group may play an even greater role in the formation of young people's identity. This was the motivation to conduct a study examining potential associations between identity formation in adolescents and the functioning of their families. The project was designed within the framework of narrative psychology and grounded in narrative identity.

Theories of narrative identity (Ricoeur, 1992, 2008; Gergen, 2000, 2001; McAdams, 1988, 1992, 1995, 1996; Keen, 1989, 1990; Hermans, 1997) are based on the assumption that language mediates in the creation, interpretation and comprehension of the world around us. According to the concept of narrative quality of all knowledge, the natural way of organizing that knowledge is to present it in the form of a narrative. Narratives enable us not only to order and grasp reality, but also to construct it in a particular manner. From this perspective, individual identity is defined as the result of self-narratives developed through social interaction and being in a specific universe of meanings. As such, it emerges through narration (Shugar, Bokus, \& Smogorzewska, 2013).

Defining "Self" in narrative terms involves constructing stories that explain and give meaning to experience. Identity formation is tantamount to the development of the personal story: a collection of narratives and their main themes ordering the course of human life and defining individuals in narrative rather than declarative terms. Identity here is construed not only as structure but also as process, and the individual as one who "is becoming" rather than one who "is". Identity is the story of one's life: an internalized, evolving life story, a personal myth (McAdams, 1988, 1992). The narrative of oneself contains personal meanings, moods, characters, problems and solutions. However, the most important element is the plot that integrates the narrative. This is the key to discovering how an individual organizes his or her personal meaning.

An important question here is whether by studying an individual's narrative, recorded at a particular time and place, we are actually gaining insight into their narrative identity. A mere analysis of a single story about oneself, without extensive, multilevel exploration as done by McAdams, indeed seems to amount to amassing identity narratives. In this approach, narrative identity would be established from a larger corpus of such stories, processed and "collected" by the individual in order to impart personal meaning on their life (Cierpka, 2013).

The stage of development is what makes the examination of budding narrative identity among adolescents particularly interesting: adolescence is the time when young people gain the ability to produce their "own narrative", becoming the biographers of their "Self". As children reach the formal operational stage and develop abstract and logical thinking, hypothetical-deductive reasoning, 
the ability to reflect, they are able to define their own ideas of good and evil, truth, norms, values, and the meaning of life. The process of formulating one's worldview and creating narrative identity is never self-contained. It is affected by the young person's relationships with family, friends, peers, and teachers. McAdams has also identified the ideological setting (a system of personal beliefs and values) as playing an important role in shaping narrative identity in adolescence. Individuals re-evaluate their opinions, norms, as well as the principles they wish to follow. By formulating personal beliefs and values, they build the foundations of their identity. There is also the issue of relationships between past, present, and future. A narrative about oneself is motivated by the search for an answer to the question "Who am I and where am I going?" Searching for an answer, young adolescents look back into the past, trying to identify "nuclear" episodes, i.e. key events and turning points in their lives which gave them a sense of being a unique individual. They try to categorize their successes and failures, and identify their causes. By ordering the past and present and formulating a vision of the future, adolescents assign meanings to various aspects of their lives. The life story integrates past, present and future into a whole that gives the narrator a sense of coherence. Telling our life story requires us to find a key to our existence. By recounting life events, we can find our place in the world of adults, achieve a sense of continuity and being the same person across various situations and times.

A key issue in the formation of individual narrative identity is participation in the family's universe of meanings, as the story is being "written" from the very beginning along family narratives, also called family ethos. By adopting the hypothesis of the narrative nature of all knowledge, we can conclude that in the "family narratological laboratory" the narratives we listen to and those we recount to others contain definitions of objects, situations, behaviors, in a word - constructs that make up the structure of meaning in the family setting (cf. Dryll \& Cierpka, 1996; Cierpka, 2004; Reiss, 1981). Each family creates its own private narrative, with unique form and content. Its structure is strongly dependent on family functioning, group structure, and the closeness of bonds between family members. The features of narratives, mediated by the family structure, may therefore control the process of individual identity formation and determine the meanings inscribed into its content (cf. Cierpka, 2002; Grotevant, 1997). Coherent, content-rich, multi-thematic and positively valuated family ethos may provide the adolescent with a foundation, a stable basis in the ever-changing world. It may be an important cornerstone for creating individual identity.

The hypothesis tested in the present study is that the features of identity narratives in adolescents are associated with their subjective evaluation of how their family functions as a whole and their assessment of their own functioning as family members. 


\section{Methods}

\section{Instruments}

The following instruments were used in the study: "Life Story" biographical method (narrative corpus) and Family Assessment Scale (assessment of family functioning).

\section{Life Story, based on the narrative interview approach devised by McAdams (1985, 1995)}

The first part of McAdams' interview, called Life Chapters ${ }^{1}$, was used in this study. Participants are asked to think about their life as if it were a book containing all of their experience. The book is divided into chapters, each describing a stage in life. There is emphasis on important moments: breakthroughs that end one stage or start another. Participants are also asked to look into the future and to give the book a title that would connect its contents into one coherent and meaningful whole.

The analysis of self-narratives followed the design based on propositional analysis of discourse, reconstruction of semantic fields, frequency analysis and selected methods of textual analysis developed in literary studies (cf. Cierpka, 2000). On the basis of individual components of the self-concept (qualities, attributes assigned by the individual and by others, and descriptions of actions), two groups of factors describing individuals were identified. The first refers to attributes individuals use to describe themselves: their number and valence (attribute network: subject's qualities or demeanor). The second comprises those variables that refer to verbs used in the participants' narratives: their category, form, mode, etc. They describe the character of actions taken by the participants, the way they function (e.g. whether they are actors or rather passive observers) and the perception of actions undertaken towards them.

Thus, in the analysis of participants' narratives all attributes (adjectives and phrases serving as adjectival attributes) that participants used to describe themselves were listed and counted. The meanings of individual attributes were analyzed using evaluative character analysis (Dryll \& Cierpka, 1996). Evaluative indices for individual participants were calculated by adding negative and positive attributes. Next, all verbs in individual narratives were listed and classified (cf. Cierpka, 2000). A number of narrative indices were identified on that basis. Network of Self-attributes:

- Relative number of Self-attributes: the share of Self-attributes in the total number of words in the narrative;

- Self-attributes' evaluation index - the total of weights of all Self-attributes (the lower the index value, the more negative the Self-concept).

\footnotetext{
${ }^{1}$ The full version of Dan McAdams' "Life Story Interview" is available at www.sesp.northwestern.edu/ foley/instruments/interview.
} 
Actions network:

- Relative number ${ }^{2}$ of all verbs describing actions undertaken by the subject (by-actions);

- Relative number of verbs describing the subject's activity: actions (I went, I passed);

- Relative number of verbs describing the subject's activity: states (I feel, I was calm);

- Relative number of verbs describing the subject's activity: attitudes (I believe that, I was positive that);

- Relative number of verbs describing activities towards the subject (they hit me, they knocked out my...) (to-actions).

Family Assessment scale - a Polish version

(cf. Beauvale \& de Barbaro, 2002; Namystowska et al., 2002)

of a German diagnostic family measure designed by M. Cierpka

and G. Frevert, based on the Process Model of Family Functioning developed by Skinner, Steinhauer and f. Santa-Barbara (2000)

The Polish version comprises three types of scales: Family Scale (overall family assessment), Dyadic Relationship Scale, Self-Assessment Scale (evaluation of the individual's own functioning within the family). Two parts of the instrument were used in the present study: the Family Scale and the SelfAssessment Scale. The instrument comprises seven subscales describing aspects of family functioning included in the model proposed by Skinner, Steinhauer and Santa-Barbara: task completion, role performance, communication, emotionality, emotional involvement, control, values and norms. The subscales in all the scales contain four items each. Responses are scored from 0 (wanted) to 3 (unwanted). The range of each scale is therefore from 0 to 12 . Higher scores indicate more severe family dysfunction in the aspect assessed by a given subscale (as such, the scale is "reversed"). For example, a low score in the "task performance" subscale may suggest that the subject views the family as flexible, capable of adapting to the demands of development. In stressful situations, functional patterns of task performance are used, and problems are solved in agreement with other family members.

Besides the seven subscales mentioned above, there is a general scale constituting the total of scores from the seven subscales. The Family Scale contains two control subscales: expectations and defense.

\section{Participants}

The participants were Polish adolescents, second-year students of high schools in Warsaw aged 17-18 years, from two-parent families of origin. Due to the requirement to write one's life story and the qualitative design of the

\footnotetext{
2 The proportion of verbs of a given category in the total number of verbs used in the narrative.
} 
study, the sample was selected in accordance with the methodological principles of narrative studies (Franzosi, 2010; Gubrium \& Holstein, 2009, StraśRomanowska, 1995).

The final sample comprised 26 high school students, including 14 females and 12 males. All participants provided informed consent to take part in the study.

\section{Variables and indices}

The explained variable is the form (features) of adolescents' narratives. The indices of the explained variable were: length of narrative, number of themes, number of thematic categories, number of Self-attributes, number of positive and negative Self-attributes, Self-evaluation index, number of family valuations, number of positive and negative family valuations, family evaluation index, number of verbs in the narrative, number of verbs describing actions, states and attitudes of the participant.

The explanatory variable in the study is adolescents' overall assessment of family and their self-assessment of their own functioning within their family. The indices of the explanatory variable were the scores on individual scales of the Family Assessment Questionnaire: task accomplishment, role performance, communication, affective expression, involvement, control, values and norms.

Quantitative analysis in the study was supplemented by qualitative analysis of narration, however, due to space constraints, the latter will be presented in a separate paper.

\section{Results}

To test the hypothesized relationships between the features of adolescents' self-narratives and selected aspects of their families' functioning, four sets of data were analyzed:

1. Analysis of the narrative as a whole ${ }^{3}$ vs. the participants' assessment of overall family functioning and self-assessment as family members;

2. Analysis of self-description features ${ }^{4}$ in the narratives vs. the participants' assessment of overall family functioning and self-assessment as family members;

3. Analysis of family description features ${ }^{5}$ in the narratives vs. the participants' assessment of overall family functioning and self-assessment as family members;

\footnotetext{
${ }^{3}$ Narrative as a whole - indices: length of narrative, number of themes, number of thematic categories.

${ }^{4}$ Self-description in narratives - indices: number of Self attributes, number of positive and negative Self attributes, Self-assessment index.

${ }^{5}$ Family description in narratives - indices: number of family valuations, number of positive and negative family valuations, family assessment index.
} 
Table 1. Overall analysis of narratives and participants' overall assessment of family functioning

\begin{tabular}{lll}
\hline NARRATIVE & $\begin{array}{l}\text { Overall Family } \\
\text { Assessment }\end{array}$ & Pearson's $r$ \\
\hline \multirow{3}{*}{ Number of thematic categories } & Affective expression & $r=-0.492, p=0.05$ \\
& Involvement & $r=-0.609, p=0.01$ \\
& Control & $r=-0.463, p=0.05$ \\
\hline
\end{tabular}

4. Analysis of the description of participants' actions $^{6}$ in the narratives vs. their assessment of overall family functioning and self-assessment as family members.

Statistically significant results that confirmed the research hypotheses will be presented (in accordance with the above sequence). The strength of relationships between dependent variables (indices based on narrative analysis) and independent ones (indices based on the Family Assessment Questionnaire) were analyzed using Pearson's $r$ (distribution was normal).

\section{1a. Relationship between attributes of the narrative as a whole and overall assessment of family functioning}

No relationships were found between the following indices: length of narrative or number of themes and the scales in the Overall Family Assessment Questionnaire. Statistically significant correlations were found for the relationship between the number of thematic categories in the participants' narratives and their assessment of the family on the following scales: Affective Expression, Control and Involvement.

Narratives feature more thematic categories (the scope of subjects discussed in life history broadens) if participants think that affective expression in their family is adequate to circumstances, family members are empathetic and care for one another without limiting each other's autonomy.

\section{1b. Relationship between attributes of the narrative as a whole and self-assessment as family member}

The relationship between self-assessment as family member and the general attributes of the narrative proved to be marginal. There were no significant relationships between self-assessment as family member and the length of selfnarrative or the number of thematic categories.

\footnotetext{
${ }^{6}$ Description of participants' own actions - indices: number of verbs in the narrative, number of action verbs, state verbs and attitude verbs.
} 
Table 2. Analysis of self-description in narratives and assessment of overall family functioning

\begin{tabular}{llc}
\hline NARRATIVE & $\begin{array}{l}\text { Family Assessment } \\
\text { Questionnaire } \\
\text { Overall Family Assessment }\end{array}$ & Pearson's r \\
\hline $\begin{array}{l}\text { Number of positive } \\
\text { Self attributes }\end{array}$ & Role Performance & $\mathrm{r}=-0.457, \mathrm{p}=0.05$ \\
\hline \multirow{2}{*}{ Self-assessment index } & Control & $\mathrm{r}=-0.476, \mathrm{p}=0.05$ \\
& Role Performance & $\mathrm{r}=-0.570, \mathrm{p}=0.01$ \\
& Communication & $\mathrm{r}=-0.521, \mathrm{p}=0.05$ \\
\hline
\end{tabular}

There was only one correlation, between the number of themes in the narrative and the Task Accomplishment Scale in the Self-Assessment Questionnaire (Pearson's $r=0.444, p=0.05$ ). The score on the Task Accomplishment Scale in the Self-Assessment Questionnaire increases with the number of narrative themes. A higher number is associated with the participants' sense that they successfully accomplish tasks given to them by their families.

\section{2a. Relationship between self-description in the narrative and assessment of overall family functioning}

Statistical analysis yielded several significant relationships between narrative self-description and assessment of family functioning.

The number of positive attributes (features, adjectives) related to Self in the narratives was negatively correlated with Role Performance and Control. The more positive Self attributes appeared in a narrative, the lower were the results on these scales. Individuals who see more positive attributes in themselves tend to perceive family roles as well-known and willingly performed by family members, and control-related behaviors in the family as flexible and predictable.

The Self-assessment index was negatively correlated with Role Performance, Communication, Control and the overall score in the Family Questionnaire. As can be seen, higher self-assessment in adolescents is associated with the perception of family roles as well-defined, understandable and approved by its members, high quality of communication (clear and direct) and flexible behavior control in the family.

\section{2b. Relationship between self-description in the narrative and self-assessment as family member}

Multiple relationships were found between elements of narrative self-description and self-assessment as family member. Only the number of positive Self 
Table 3. Analysis of self-description in narratives and self-assessment as family member

\begin{tabular}{lll}
\hline NARRATIVE & $\begin{array}{l}\text { Family Assessment } \\
\text { Questionnaire } \\
\text { Self-Assessment }\end{array}$ & Pearson's $r$ \\
\hline \multirow{2}{*}{ Number of Self attributes } & Task Accomplishment & $r=0.436, p=0.05$ \\
& Control & $r=-0.440, p=0.05$ \\
\hline \multirow{2}{*}{ Number of positive Self attributes } & Communication & $r=-0.457, p=0.05$ \\
& Control & $r=-0.594, p=0.01$ \\
\hline \multirow{2}{*}{ Number of negative Self attributes } & Task Accomplishment & $r=0.629, p=0.01$ \\
& Affective expression & $r=0.481, p=0.05$ \\
& Involvement & $r=0.389, p=0.05$ \\
\hline \multirow{2}{*}{ Self-assessment index } & Role Performance & $r=-0.435, p=0.05$ \\
& Communication & $r=-0.565, p=0.05$ \\
& Control & $r=-0.632, p=0.01$ \\
\hline
\end{tabular}

attributes and negative Self attributes was not correlated with the Self-Assessment Questionnaire. All the remaining indices and their significant relationships are shown in Table 3.

The number of Self attributes was correlated with Task Accomplishment and Control (negatively). A greater number of attributes related to Self is therefore associated with a sense of family task accomplishment below expectations and successful behavior control (in line with one's expectations).

The number of positive attributes related to Self in the narratives was negatively correlated with Communication and Control. The more positive Self attributes appeared in a narrative, the lower were the results on these scales.

The number of negative Self attributes was positively correlated with Task Accomplishment, Affective Expression, and Involvement. A greater number of negative attributes related to Self is therefore associated with a sense of not accomplishing tasks in the family as expected and unsatisfactory emotional involvement in the family.

A higher index of self-assessment is associated with the perception of adequate functioning within the family: adolescents who evaluate themselves positively in the narratives are aware of their family role and happy to perform it, communicate with other family members competently, openly and effectively and have a sense of being in control of their lives and family roles. 
Table 4. Analysis of family description and assessment of overall family functioning

\begin{tabular}{lll}
\hline NARRATIVE & $\begin{array}{l}\text { Family Assessment } \\
\text { Questionnaire } \\
\text { Overall Family Assessment }\end{array}$ & Pearson's $r$ \\
\hline $\begin{array}{l}\text { Number of negative } \\
\text { family valuations }\end{array}$ & $\begin{array}{l}\text { Values and norms } \\
\text { Communication }\end{array}$ & $r=0.615, p=0.01$ \\
\hline Family assessment index & Control & $r=0.484, p=0.05$ \\
\hline $\begin{array}{l}\text { Number of negative } \\
\text { family valuations }\end{array}$ & All scales total & $r=-0.483, p=0.05$ \\
\hline
\end{tabular}

\section{3a. Relationship between the way adolescents describe their families and their assessment of overall family functioning}

Statistical analysis yielded several significant correlations between narrative descriptions of the family and its assessment in the questionnaire.

The number of negative attributes related to family was positively correlated with Communication and Norms/Values, as well as the overall questionnaire score. Family-related negative attributes coincide in the narratives with negative assessment of information flow between family members and the family system of values and norms (lack of compatibility and consistency). Individuals whose narratives featured multiple negative valuations related to family evaluated the overall functioning of the family system as maladaptive.

On the other hand, predictable and appropriately flexible control in the family is associated with significantly higher evaluation of the system (negative correlation between family assessment and Control).

\section{3b. Relationship between the way adolescents describe their families and their assessment of themselves as family members}

A number of significant relationships were found between the way family is described in the narratives of teenagers in the study and their self-assessments as family members.

Participants used more negative attributes and statements to describe their whole family when they perceived a problem with adequate expression of emotions in their interactions with other family members (number of negative valuations correlated with Affective Expression).

The family assessment index was negatively correlated with Communication and Affective Expression, as well as with the overall score in the self-assessment questionnaire. Higher evaluation of family in narratives was associated with the 
Table 5. Analysis of family description in narratives and self-assessment as family member

\begin{tabular}{lll}
\hline NARRATIVE & $\begin{array}{l}\text { Family Assessment } \\
\text { Questionnaire } \\
\text { Self-Assessment }\end{array}$ & Pearson's $r$ \\
\hline Number of negative Self attributes & Affective expression & $r=0.414, p=0.05$ \\
\hline \multirow{2}{*}{ Self-assessment index } & Communication & $r=-0.431, p=0.05$ \\
& Affective expression & $r=-0.461, p=0.05$ \\
& All scales total & $r=-0.497, p=0.05$ \\
\hline
\end{tabular}

perception of communication with family members as open and clear, and emotions in interactions as adequate. The overall assessment of oneself as a family member is also significantly more positive when the family assessment index in narratives is higher.

\section{4a. Relationship between the way adolescents describe their parents in narratives and their assessment of overall family functioning}

Statistical analysis yielded several significant relationships between narrative description of parents and assessment of family functioning.

Using many negative attributes to describe parents is associated with the perception of family relations as inadequate - either too close or too distant, and the system of family values as inconsistent and overly restrictive for individual members. There is also a lack of inclination to portray the family in a more positive light (number of negative valuations and Defense scale).

Table 6. Analysis of parents' description in narratives and overall family assessment

\begin{tabular}{lll}
\hline NARRATIVE & $\begin{array}{l}\text { Family Assessment } \\
\text { Questionnaire } \\
\text { Overall Family } \\
\text { Assessment }\end{array}$ & Pearson's $r$ \\
\hline Parent assessment index & Control & $r=-0.482, p=0.05$ \\
\hline Number of negative valuations & Involvement & $r=0.463, p=0.05$ \\
& Values and norms & $r=0.598, p=0.01$ \\
& Defense & $r=0.042, p=0.05$ \\
\hline
\end{tabular}


Table 7. Analysis of parents' description in narratives and self-assessment as family member

\begin{tabular}{lll}
\hline NARRATIVE & $\begin{array}{l}\text { Family Assessment } \\
\text { Questionnaire } \\
\text { Self-Assessment }\end{array}$ & Pearson's $r$ \\
\hline \multirow{2}{*}{ Number of negative valuations } & Affective expression & $r=0.476, p=0.05$ \\
& Involvement & $r=0.509, p=0.05$ \\
\hline \multirow{2}{*}{ Parent assessment index } & Task Accomplishment & $r=-0.440, p=0.05$ \\
& Affective expression & $r=-0.441, p=0.05$ \\
& Control & $r=-0.447, p=0.05$ \\
& Values and norms & $r=-0.522, p=0.05$ \\
\hline
\end{tabular}

By contrast, higher assessment of parents in narratives is associated with the perception of control in the family as flexible and predictable, allowing individual family members sufficient control over their lives.

\section{4b. Relationship between the way adolescents describe their parents in narratives and their self-assessment as family members}

Statistical analysis yielded several significant relationships between narrative description of parents and self-assessment of narrators as family members.

A higher number of negative attributes describing parents used in the narratives was associated with the perception of affective expression in relationships with other family members as inadequate, and emotional involvement in relationships with them as maladaptive - either too weak or too strong.

A higher index of parents' assessment in the narratives was associated with the perception of narrators' task accomplishment in the family as functional and approved by the family, an optimal level of own affective expression, a sense of being in control of one's functioning in the family and the narrators' system of values being compatible with family norms.

In general, a higher index of parents' assessment in the narrative is associated with higher overall self-assessment of adolescents as family members $(r=-0.527$, $p=0.05)$.

\section{Relationship between the way adolescents describe their conduct in narratives and their assessment of overall family functioning and self-assessment}

No statistically significant relationships were found between narrative description of conduct and assessment of overall family functioning. 
The majority of narrative indices of conduct were not significantly correlated with participants' self-assessment as family members. The only relationship emerged between the number of verbs used in narratives to describe the narrators' states and the Task Accomplishment scale $(r=0.407, p=0.05)$. A positive correlation here means that the more participants describe their experiences in various situations and focus on feelings, the more likely they are to perceive themselves and their family as incapable of adaptive change (in response to developmental challenges).

\section{Conclusions}

The analysis of adolescents' narratives and data on their perception of family demonstrated a relationship between personal story formation (identity narrative) and some domains of family functioning. It should be noted here that the functioning of adolescents' families was analyzed across seven different dimensions ${ }^{7}$, with some relationships between narrative and family variables proving to be significant.

Self-narratives were highly varied and featured a wide variety of themes when adolescents assessed the flow of emotions and level of emotional involvement in the family as adequate, and the level of control as optimal. Thus, the most important factors for a rich and multi-thematic personal narrative of a teenager proved to be adequate affective expression in the family, empathic competence of family members and mutual care, although the kind that does not limit the autonomy of others.

A higher index of narrative self-evaluation is associated with successful performance of family roles, clear and open communication within the system and an optimal level of control. Adolescents whose identity narratives are permeated with positive valuations tend to perceive family roles as well-known and willingly performed by family members, and control-related behaviors in the family as flexible and predictable. A safe, familiar context helps build a positive self-image in a consistent framework of one's personal history. What comes to the fore here is the ability of all family members to comprehend their roles. Clearly agreed and defined mutual obligations and expectations may thus have a significant effect on the adolescents' evaluation of Self in their narratives.

The previously mentioned predictable and appropriately flexible control in the entire family also proves vital for a higher evaluation of the family system as described by adolescents in their narratives and for a higher value of the parents' assessment index. A highly positive evaluation of family by adolescents is thus primarily associated with optimal (moderate) mutual influence (control) between

\footnotetext{
Aspects of family functioning according to Skinner and Steinhauer's model: task accomplishment, family role performance, communication, affective expression, emotional involvement, control, values and norms.
} 
family members. A sense of independence and flexible boundaries appear to be the main criteria for adolescents' assessment of family.

By contrast, unclear communication, lack of well-defined, consistent values and norms are associated with a greater number of negative attributes with respect to family, while a low level of emotional involvement in the family and lack of explicit values and norms - with an abundance of negative attributes used to describe parents. The conclusion seems to be particularly interesting: adolescents need a dependable point of reference, explicit, clearly specified values and norms shared by the family. They need a clear structure, stable framework, rules to structure their world, affording them peace of mind to construct their personality. This is a particularly important finding in the context of ongoing discussions about difficulties in raising young people.

A consistent picture emerges from the relationships between adolescents' self-narratives and their assessment of themselves as family members. Low evaluation of the narrators' task accomplishment in the family is associated with an increased number of narrative themes and attributes related to self. This is the process which Ricoeur (1992) described as "narrative maintenance of self": the teenagers' need to better define themselves, to understand the sense of inadequacy in their family functioning. The challenges they encounter provide the impulse to create narratives which help make sense of their experience and structure it into a coherent semantic whole. Accomplishment of tasks in the family appears to be important to adolescents to the extent that a conflict in that domain forces them to halt the self-narrative and work through certain subjects.

On the other hand, a sense of successful role performance, assessment of one's communication as open and behavior control as optimal, is associated with a higher index of self-assessment in the narrative. These dimensions of self-perception as family members are important for young people's overall selfassessment and determine the rate of positive attributes describing the narrators in their accounts. Thus, successful performance of family roles appears to be an important aspect of self-esteem in adolescence.

Assessment of one's communication as clear, emotionality as adequate and overall higher self-assessment is associated with a higher family assessment index in the narrative, while seeing one's emotionality as inadequate is associated with a higher number of negative attributes ascribed to the family. Positive self-assessment in the above domains corresponds with a positively valued narrative about family. Similar relationships are found in the assessment of parents. Adequate accomplishment of one's tasks in the family, an optimal level of affective expression, a sense of being in control of one's functioning in the family and a system of values consistent with family norms (overall higher self-esteem) is associated with a higher index of evaluation of parents in the narrative, while inadequate affective expression and involvement coincide with a greater number of negative attributes ascribed to parents. 
To sum up, multi-thematic, content-rich and positively valuated self-narratives in adolescents are determined by selected aspects of positive assessment of the family and subjects' own functioning within the family system. These aspects are the level of behavioral control, role performance and communication in the family. We can therefore hypothesize that a flexible level of control in the family, clear and well-defined roles and open communication may significantly support a functional construction of adolescents' identity, i.e. building one's life story based on the strength and structural clarity of the family system. We still need to assess the significance of adolescents' narratives for the functioning of their families, since we are obviously exploring the above relationships taking into account the covariance of the two categories of variables (their circularity). Further research is therefore required to elucidate specific directions of the covariance of interest.

\section{References}

Arnett, J.J. (2000). Emerging adulthood: A theory of development from the late teens through the twenties. American Psychologist, 55 (5), 469-480.

Cierpka, A. (2000). Metody analizy narracji w badaniach psychologicznych [Methods of narrative analysis in psychological studies]. In M. Straś-Romanowska (Ed.), Metody jakościowe w psychologii wspótczesnej [Qualitative Methods in Contemporary Psychology] (pp. 129-139). Wrocław: Wydawnictwo Uniwersytetu Wrocławskiego.

Cierpka, A. (2002). Tożsamość jednostki wśród rodzinnych narracji [Individual identity among family narratives]. In J. Trzebiński (Ed.), Narracja jako sposób rozumienia świata [Narrative as a Way of Grasping the World] (pp. 173-187). Gdańsk: Gdańskie Wydawnictwo Psychologiczne.

Cierpka, A. (2004). Narracje rodzinne w procesie kształtowania się tożsamości człowieka [Family narratives in the process of identity formation]. In E. Dryll \& A. Cierpka (Eds.), Narracja, koncepcje i badania psychologiczne [Narration, Concepts and Psychological Studies] (pp. 115-132). Warszawa: Wydawnictwo Instytutu Psychologii PAN.

Cierpka, A. (2013). Tożsamość i narracje w relacjach rodzinnych [Identity and Narratives in Family Relations]. Warszawa: Eneteia, Wydawnictwo Psychologii i Kultury.

Dryll, E. \& Cierpka, A. (1996). Badanie treści etosu rodzinnego poprzez analizę narracji [Examination of the contents of family ethos through narrative analysis]. Kwartalnik Polskiej Psychologii Rozwojowej, 4 (1), 33-52.

Franzosi, R. (2010). Quantitative Narrative Analysis. Thousand Oaks, CA: Sage Publications.

Gergen, K. \& Gergen, M. (2000). The Saturated Self. New York: Basic Books.

Gergen, K.J. (2001). Psychological science in a postmodern context. American Psychologist, 56 (10), 803-813. 
Grotevant, H.D. (1997). Family processes, identity development, and behavioral outcomes for adopted adolescents. Journal of Adolescent Research, 12(1), 139-161. Gubrium J. \& Holstein J. (2009). Analyzing Narrative Reality. Thousand Oaks, CA: Sage Publications.

Hermans, H. (1997). Self-narrative in the life course: A contextual approach. In M. Bamberg (Ed.), Narrative Development: Six Approaches (pp. 223-264). Mahwah, NJ: Lawrence Erlbaum Associates.

Keen, S. (1989). Your Mythic fourney. Finding Meaning in Your Life through Writing and Storytelling. Los Angeles, CA: Tarcher.

Keen, S. (1990). Storytelling and the discovery of identity. In S. Keen (Ed.), To a Dancing God. Notes of a Spiritual Traveler. San Francisco: Harper.

Kroger, J., Martinussen, M., \& Marcia, J.E. (2010). Identity status change during adolescence and young adulthood. A meta-analysis. Fournal of Adolescence, 33 (5), 683-698.

McAdams, D.P. (1985). Power, Intimacy and the Life Story. Personological Inquiries into Identity. Homewood, IL: Dorsey Press.

McAdams, D.P. (1988). Biography, narrative and lives: An introduction. fournal of Personality, 56 (1), 1-18.

McAdams, D.P. (1992). The five-factor model in personality: A critical appraisal. Journal of Personality, 60 (2), 329-361.

McAdams, D.P. (1995). What do we know when we know a person? Journal of Personality, 63 (3), 365-396.

McAdams, D.P. (1996). Personality, modernity and the storied self: A contemporary framework for studying persons. Psychological Inquiry, 7 (4), 295-321.

McLean, K.C, Breen, A.V., \& Fournier, M.A. (2010). Constructing the Self in early, middle and late adolescent boys: Narrative identity, individuation and wellbeing. Research on Adolescence, 20 (1), 166-187.

Namysłowska, I., de Barbaro, B., Paszkiewicz, E., Siewierska, A., Furgał, M., Drożdżowicz, L., Józefik, B., \& Beauvale, A. (2002). Kwestionariusze Manfreda Cierpki do Oceny Rodziny [Manfred Cierpka Family Assessment Questionnaires]. Psychiatria Polska, 36 (1), 17-28.

Prinstein, M.J. \& Dodge, K.A. (Eds.) (2008). Understanding Peer Influence in Children and Adolescents. New York: Guilford Press.

Reiss, D. (1981). The Family's Construction of Reality. Cambridge, MA: Harvard University Press.

Ricoeur, P. (1992). Filozofia osoby [Philosophy of the Person]. Warszawa: PAT.

Ricoeur, P. (2008). Czas i opowieść [Time and Narrative]. Kraków: Wydawnictwo Uniwersytetu Jagiellońskiego.

Robin, R. (1980). Badanie pól semantycznych: doświadczenie OLP w Saint-Cloud [Semantic field analysis: experience of the Saint-Cloud Political Lexicography Center]. In M. Głowiński (Ed.), Jezzk i społeczeństwo [Language and Society]. Warszawa: Czytelnik. 
Shugar, G.W, Bokus, B., \& Smogorzewska, J. (2013). From Reference Situation to Narrative Text. Piaseczno: Studio Lexem.

Skinner, H., Steinhauer, P., \& Sitarenios, G. (2000). Family Assessment Measure (FAM) and process model of family functioning. Fournal of Family Therapy, 22 (2), 190-210.

Straś-Romanowska, M. (Ed.) (1995). Na tropach psychologii jako nauki humanistycznej [Psychology as a Branch of the Humanities]. Warszawa: Wydawnictwo Naukowe PWN. 